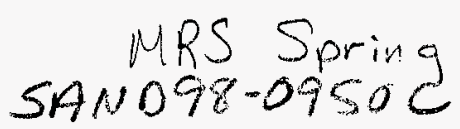

\title{
ULTRA-HIGH IMPLANT ACTIVATION EFFICIENCY IN GaN USING NOVEL HIGH TEMPERATURE RTP SYSTEM SAND- $98-0950 \mathrm{C}$

X. A. Cao *, C. R. Abernathy *, R. K. Singh *, S. J. Pearton *, M. Fu **, V. Sarvepalli **, J. A. Sekhar $* *$, J. C. Zolper ***, D. J. Rieger $* * * *$, J. Han ****, T. J. Drummond ****, R. J. Shul $* * * *$ and $\mathrm{R}$. G. Wilson *****

* Department of Materials Science and Engineering, University of Florida, Gainesville, FL 32611 USA

** Micropyretics Heaters international, Inc. Cincinnati, OH 45212 USA

*** Office of Naval Research, Arlington, VA 22217 USA

**** Sandia National Laboratories, Albuquerque, NM 87185 USA

***** Consultant, Stevenson Ranch, CA 91381 USA

RECEIVED

APR 299998

OSTI

\section{ABSTRACT}

$\mathrm{Si}^{+}$implant activation efficiencies above $90 \%$, even at doses of $5 \times 10^{15} \mathrm{~cm}^{-2}$, have been achieved in GaN by RTP at $1400-1500^{\circ} \mathrm{C}$ for 10 secs. The annealing system utilizes with $\mathrm{MoSi}_{2}$ heating elements capable of operation up to $1900{ }^{\circ} \mathrm{C}$, producing high heating and cooling rates (up to $100^{\circ} \mathrm{C} \cdot \mathrm{s}^{-1}$ ). Unencapsulated $\mathrm{GaN}$ show severe surface pitting at $1300^{\circ} \mathrm{C}$, and complete loss of the film by evaporation at $1400^{\circ} \mathrm{C}$. Dissociation of nitrogen from the surface is found to occur with an approximate activation energy of $3.8 \mathrm{eV}$ for GaN (compared to $4.4 \mathrm{eV}$ for AlN and $3.4 \mathrm{eV}$ for $\mathrm{InN}$ ). Encapsulation with either rf-magnetron reactively sputtered or MOMBE-grown AlN thin films provide protection against $\mathrm{GaN}$ surface degradation up to $1400^{\circ} \mathrm{C}$, where peak electron concentrations of $\sim 5 \times 10^{20} \mathrm{~cm}^{-3}$ can be achieved in Si-implanted GaN. SIMS profiling showed little measurable redistribution of $\mathrm{Si}$, suggesting $D_{\mathrm{Si}} \leq 10^{-13} \mathrm{~cm}^{2} \cdot \mathrm{s}^{-1}$ at $1400{ }^{\circ} \mathrm{C}$. The implant activation efficiency decreases at higher temperatures, which may result from $\mathrm{Si}_{\mathrm{Ga}}$ to $\mathrm{Si}_{\mathrm{N}}$ site switching and resultant self-compensation.

\section{Introduction}

Ion implantation is an enabling technology for fabrication of $\mathrm{GaN}$-based ultra-high power thrysistors, junction field-effect transistors (JFETs) and heterostructure field effect transistors (HFETs $)^{(1-10)}$. In particular selective area implantation can be used to reduce transistor access resistance by creating highly doped contact regions. Most published device characteristics show evidence of relatively high access resistances ${ }^{(11-14)}$. To date GaN JFETs formed entirely by implantation into undoped material ${ }^{(2)}$ and GaN light emitting diodes (LEDs) formed by $\mathrm{Mg}^{+}$ implantation into n-type epi layers ${ }^{(15)}$ are the only devices fabricated using implant doping.

Past work has shown that in compound semiconductors the annealing temperature required for implant activation is a fairly high percentage of the melting temperature of the material, and is also a function of the implant dose $\mathrm{e}^{(16,17)}$. In $\mathrm{GaN}$ it has been observed that low dose $\left(\leq 5 \times 10^{14}\right.$ $\mathrm{cm}^{-2}$ ) implants anneal poorly up to $1100{ }^{\circ} \mathrm{C}$, leaving a coarse network of extended defects, while high dose ( $\geq 2 \times 10^{15} \mathrm{~cm}^{-2}$ ) implants may lead to amorphization. Amorphous layers recrystallize in the range $800-1000^{\circ} \mathrm{C}$ to form defective polycrystalline material ${ }^{(18)}$. Quite good activation efficiencies have been obtained for $n$-type implanted dopants in spite of high residual damage ${ }^{(19-}$ ${ }^{21)}$. It is also clear that annealing temperatures above $1300^{\circ} \mathrm{C}$ are desirable for optimal electrical properties in the implanted layers ${ }^{(19,20)}$. The equilibrium $\mathrm{N}_{2}$ pressure over $\mathrm{GaN}$ at $1400{ }^{\circ} \mathrm{C}$ is $>$ 1000 bar $^{(22,23)}$, and at these temperatures only two methods have proven effective in preventing

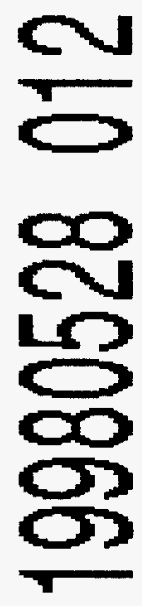




\section{DISCLAIMER}

This report was prepared as an account of work sponsored by an agency of the United States Government. Neither the United States Government nor any agency thereof, nor any of their employees, makes any warranty, express or implied, or assumes any legal liability or responsibility for the accuracy, compieteness, or usefulness of any information, apparatus, product, or process disclosed, or represents that its use would not infringe privately owned rights. Reference herein to any specific commercial product, process, or service by trade name, trademark, manufacturer, or otherwise does not necessarily constitute or imply its endorsement, recommendation, or favoring by the United States Government or any agency thereof. The views and opinions of authors expressed herein do not necessarily state or reflect those of the United States Government or any agency thereof. 
surface decomposition. The first is use of high $\mathrm{N}_{2}$ pressures $(15 \mathrm{kbar})^{(24)}$, and the second is deposition of AlN encapsulation layers ${ }^{(25)}$ (at $1400^{\circ} \mathrm{C}$ the equilibrium $\mathrm{N}_{2}$ pressure above $\mathrm{AlN}$ is only $10^{-8} \mathrm{bar}$ ).

In this paper we report use of a new high-temperature rapid thermal processing system for annealing of implanted $\mathrm{GaN}$ at temperatures up to $1500^{\circ} \mathrm{C}$. When used in conjunction with AlN cap layers, very high activation efficiencies $\left(\geq 90 \%\right.$ ) can be obtained even for $\mathrm{Si}^{+}$ion doses of 5 $\times 10^{15} \mathrm{~cm}^{-2}$. This approach is attractive for processing of $\mathrm{GaN}$ devices in a conventional fabrication-line environment, without the need for specialized high-pressure furnaces.

\section{Experimental}

Undoped $\left(\mathrm{n} \sim 1-8 \times 10^{16} \mathrm{~cm}^{-3}\right) \mathrm{GaN}$ films 2-3 $\mu \mathrm{m}$ thick were grown on $\mathrm{Al}_{2} \mathrm{O}_{3}$ substrates at $\sim 1040^{\circ} \mathrm{C}$ by Metal Organic Chemical Vapor Deposition. $\mathrm{Si}^{+}$ions were implanted at $25^{\circ} \mathrm{C}$ to a dose of $5 \times 10^{15} \mathrm{~cm}^{-2}$ at an energy of $100 \mathrm{keV}$. This produces a maximum Si concentration at a projected range of $800 \AA$, according to a Transport-of-Ions-in-Matter calculation. The samples were deposited with AlN by reactive sputtering or by Metal Organic Molecular Beam Epitaxy, and were sealed in quartz ampoules under $\mathrm{N}_{2}$ gas at $15 \mathrm{psi}$ (the slight negative pressure was to prevent ampoule blow-out at elevated temperature). Annealing was performed in an MHI Zapper RTP furnace containing novel molybdenum intermetallic composite heating elements. These are maintained at constant temperature, and a motor driven actuator is used to achieve high ramp-up and ramp-down rates by inserting or removing the sample. Annealing was performed at 1100$1500{ }^{\circ} \mathrm{C}$ for dwell times of $10 \mathrm{secs}$. The samples were characterized by scanning electron microscopy, atomic force microscopy, Hall measurements (using alloyed $420^{\circ} \mathrm{C}, 180$ secs Inbased contacts), and by Secondary Ion Mass Spectrometry (SIMS) using a cameca system and a $\mathrm{Cs}^{+}$ion beam.

\section{Results and Discussion}

A typical temperature-time profile for an annealing cycle is shown in Figure 1. Excellent temperature uniformity $\left(\leq \pm 4{ }^{\circ} \mathrm{C}\right.$ over a $9 \times 6^{\prime \prime}$ area at $\left.1500^{\circ} \mathrm{C}\right)$ and reproducibility was obtained. When unencapsulated samples were annealed, the $\mathrm{GaN}$ surface remained of reasonable quality at $1200{ }^{\circ} \mathrm{C}$, at $1300^{\circ} \mathrm{C}$ hexagonal pits at high density $\left(\sim 10^{8} \mathrm{~cm}^{-2}\right)$ were observed with substantial loss of material, at $1400{ }^{\circ} \mathrm{C}$ only the AlN buffer layers remained, while at $1500{ }^{\circ} \mathrm{C}$ even this generally peeled away to leave only the $\mathrm{Al}_{2} \mathrm{O}_{3}$ substrate. By contrast, AlN-capped samples retained good quality surfaces to $>1400{ }^{\circ} \mathrm{C}$. Occasional localized cap failures were observed, and potential mechanisms for these are currently under investigation. One possibility is agglomeration of residual $\mathrm{H}_{2}$ in the AlN to form bubbles which evolve from the material. From temperature-dependent studies we measured activation energies for $\mathrm{N}_{2}$ loss of $\sim 3.8 \mathrm{eV}$ for GaN and $4.4 \mathrm{eV}$ for $\operatorname{AlN}^{(26)}$.

Electrical results for activated samples are shown in Figure 2. Note that in unencapsulated samples the sheet electron density increases with annealing temperature up to $1200{ }^{\circ} \mathrm{C}$, but this was the highest temperature we could obtain data for due to loss of the film. By contrast, the AIN encapsulated samples showed a peak in the sheet electron density at $1400^{\circ} \mathrm{C}$, with a reduction at $1500^{\circ} \mathrm{C}$. Note that the $300 \mathrm{~K}$ electron mobility decreases at $1500^{\circ} \mathrm{C}$, indicating that the material is becoming more compensated. This behavior is fairly typical of Si implant activation in III-V materials, and is usually ascribed to self-compensation through Si site-switching, i.e. some of the $\mathrm{Si}_{\mathrm{Ga}}$ donors move to $\mathrm{Si}_{\mathrm{N}}$ sites, producing self-compensation. Note that with a peak $\mathrm{Si}$ activation efficiency of $\sim 90 \%$, the corresponding peak electron concentration will be $\sim 5 \times 10^{20} \mathrm{~cm}^{-3}$. This 
very high doping level produces extremely good specific contact resistances for $\mathrm{W}$ and $\mathrm{WSi}_{\mathrm{x}}$ metallization, with values $\leq 10^{-6} \Omega \cdot \mathrm{cm}^{2}$ after annealing in the range $600-900{ }^{\circ} \mathrm{C}$. This demonstrates the efficiency of the implantation approach for reducing contact resistances in $\mathrm{GaN}$ electronic devices.

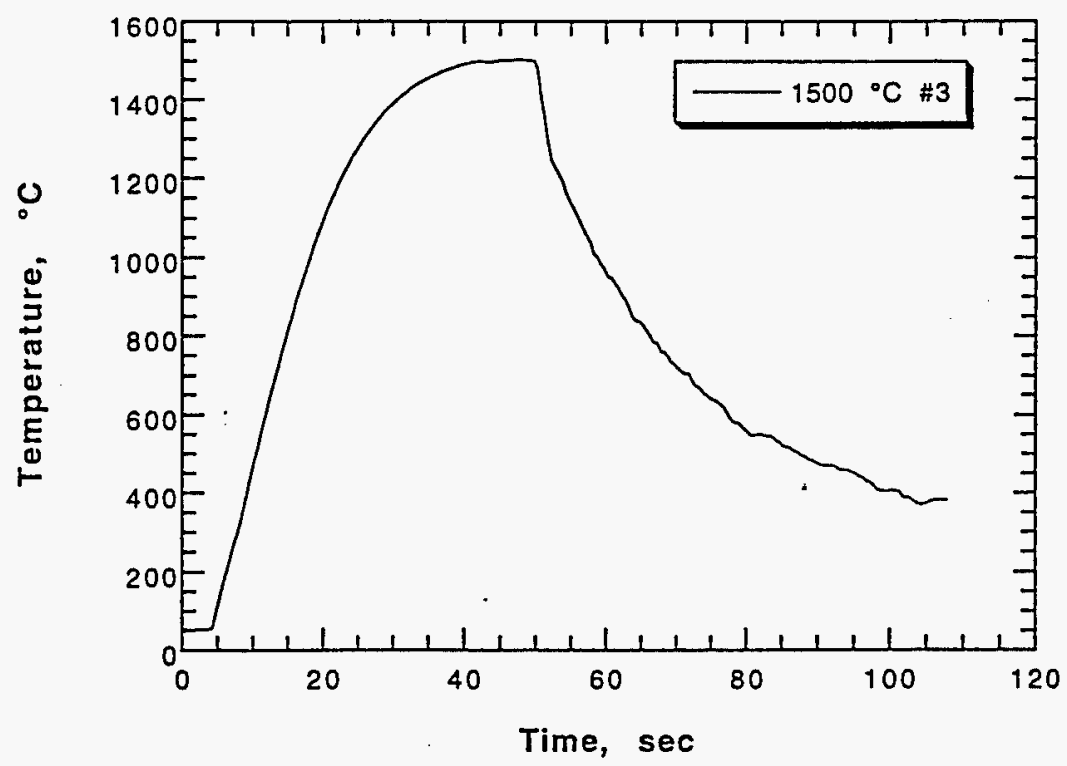

Figure 1. Time-temperature profiles for RTP annealing of $\mathrm{GaN}$ at $1500^{\circ} \mathrm{C}$.

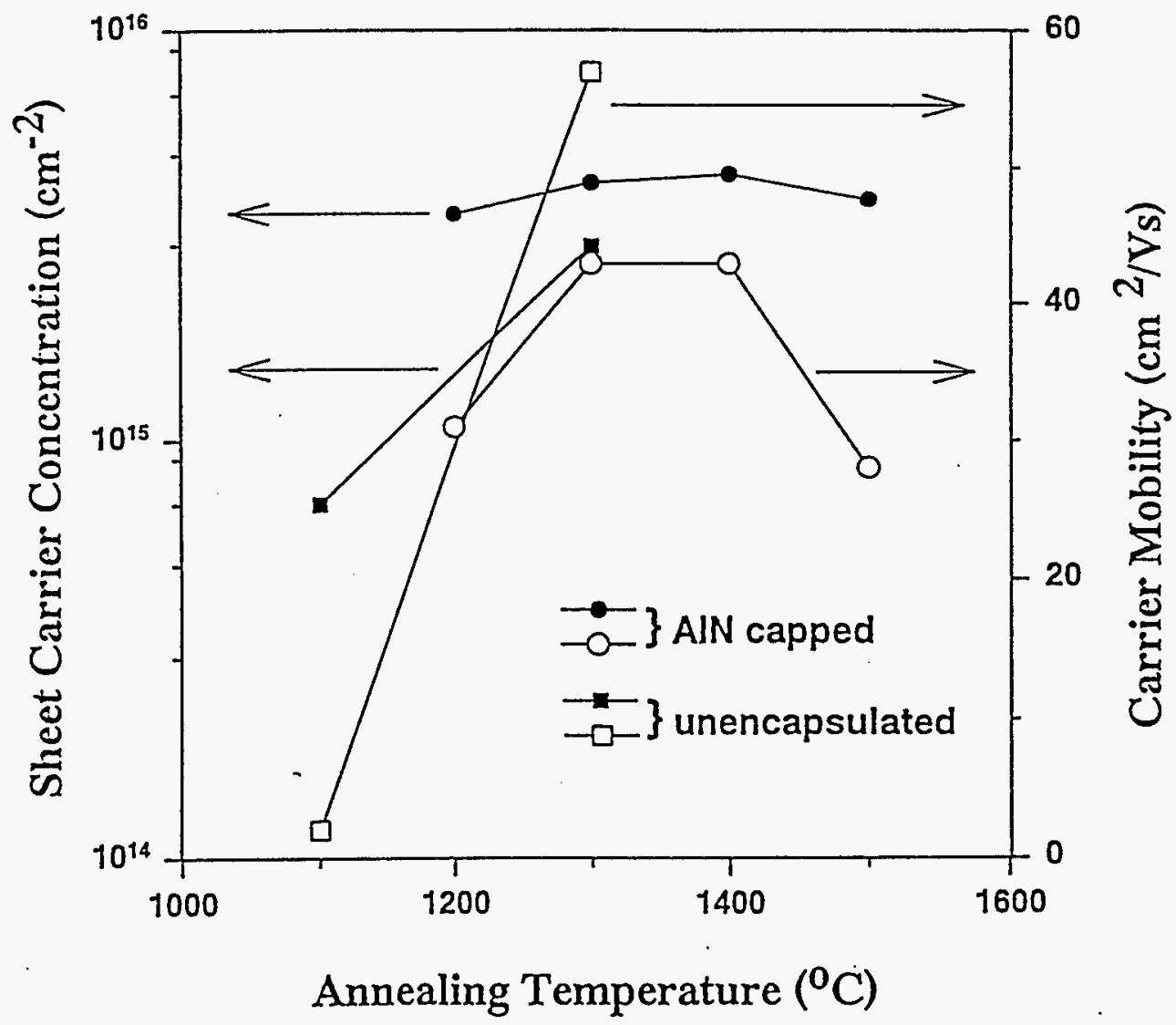

Figure 2. Sheet carrier density and electron mobility in Si implanted GaN after uncapped or AlN-capped annealing. 
Figure 3 shows the calculated, as-implanted $\mathrm{Si}$ atomic profile, and the SIMS profiles of asimplanted and $1400^{\circ} \mathrm{C}$ annealed samples. There are several obvious points in the data. First, the Profile Code algorithm does not produce a good match to the experimental profile, and some work will need to be done to obtain better stopping power data for the ions in GaN. Second, there is little redistribution of the $\mathrm{Si}$ at $1400^{\circ} \mathrm{C}$, with $\mathrm{D}_{\mathrm{Si}} \leq 10^{-13} \mathrm{~cm}^{2} \cdot \mathrm{s}^{-1}$ at this temperature calculated from the change in width at half-maximum. This result emphasizes the extremely stable nature of dopants in $\mathrm{GaN}$ even at very high processing temperatures.

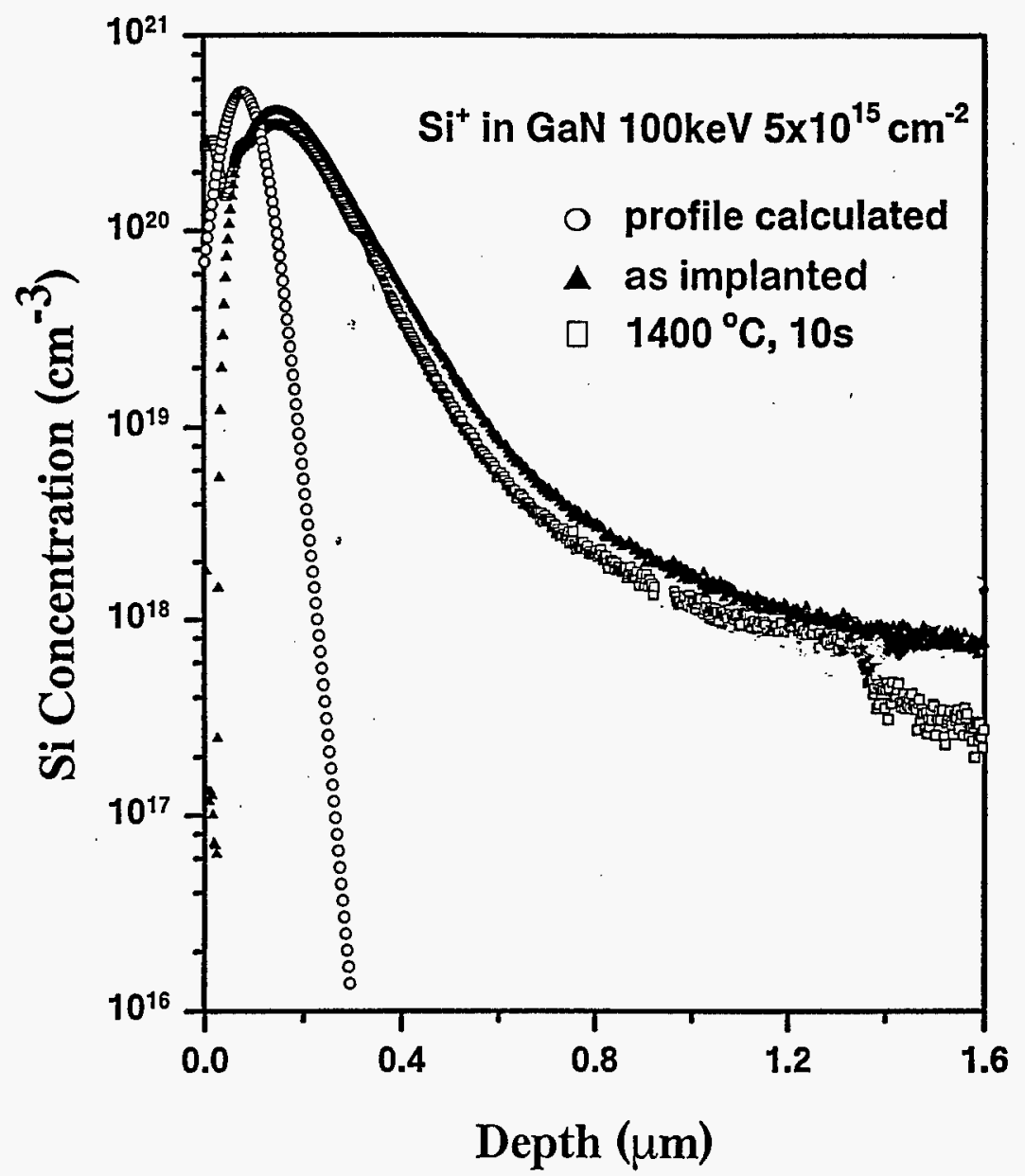

Figure 3. Calculated (from PCODE) and experimentally measured (by SIMS) profiles of implanted Si $\left(100 \mathrm{keV}, 5 \times 10^{15} \mathrm{~cm}^{-2}\right)$ in $\mathrm{GaN}$.

\section{SUMMARY AND CONCLUSIONS}

To produce low specific contact resistances in selected area of GaN-based electronic devices, ion implantation is an attractive option. However, to achieve high doping levels, high implant doses and therefore high annealing temperatures are required. The major difficulty with processing $\mathrm{GaN}$ above $\sim 150{ }^{\circ} \mathrm{C}$ is prevention of surface dissociation. The use of AlN encapsulation works well to temperatures of $\geq 1400^{\circ} \mathrm{C}$, where Si implant activation efficiency is a maximum for high dose $\left(5 \times 10^{15} \mathrm{~cm}^{-2}\right)$ conditions. The activation efficiency decreases at higher temperatures, along with a decrease in electron mobility, which is consistent with Si selfcompensation. 


\section{ACKNOWLEDGEMENTS}

The work of UF is partially supported by grants from NSF-DMR (L. Hess), DARPA/EPRI (E. R. Brown/J. Melcher) and a sub-contract from MHI, who are supported by a BMDO SBIR grant (F19628-97-C-0092) monitored by Dr. Joe Lorenzo. R. G. Wilson is partially supported by a grant from ARO (Dr. J. M. Zavada). Sandia is a multiprogram laboratory operated by Sandia Corporation, a Lockheed-Martin company, for the US Department of Energy under contract No. DE-AC04-94AL85000.

\section{References}

1. S. C. Binari, L. B. Rowland, W. Kruppa, G. Kelner, K. Doverspike and D. K. Gaskill, Electron. Lett. 301248 (1994).

2. J. C. Zolper, R. J. Shul, A. G. Baca, R. G. Wilson, S. J. Pearton and R. A. Stall, Appl. Phys. Lett. $\underline{68} 2273$ (1996).

3. J. C. Zolper, in GaN and Related Materials (Gordon and Breach, NY 1997).

4. J. C. Zolper and R. J. Shul, MRS Bulletin 2236 (1997).

5. J. C. Zolper, M. H. Crawford, S. J. Pearton, C. R. Abernathy, C. B. Vartuli, C. Yuan and R. A. Stall, J. Electron. Mater. 25839 (1996).

6. J. C. Zolper, R. G. Wilson, S. J. Pearton and R. A. Stall, Appl. Phys. Lett. 681945 (1996).

7. H. H. Tan, J. S. Williams, J. Zou, D. J. H. Cockayne, S. J. Pearton and R. A. Stall, Appl. Phys. Lett. 692364 (1996).

8. J. C. Zolper, M. H. Crawford, H. H. Tan, J. S. Williams, J. Zou, D. J. H. Cockayne, S. J. Paerton and R. F. Karlicek, Appl. Phys. Lett. 702729 (1997).

9. S. Strite, P. W. Epperlein, A. Dommen, A. Rockett and R. F. Broom, Mat. Res. Soc. Symp. Proc. 395795 (1996).

10. N. Parikh, A. Suvkhanov, M. Lioubtchenko, E. Carlson, M. Bremser, D. Bray, R. Davis and J. Hunn, Nucl. Instr. Meth. B 127/128 463 (1997).

11. J. Burm, K. Chu, W. A. Davis, W. J. Schaff, L. F. Eastman and T. J. Eustis, Appl. Phys. Lett. 70464 (1997).

12. Q. Chen, M. A. Khan, J. W. Yang, C. J. Sun, M. S. Shur and H. Park, Appl. Phys. Lett. $\underline{69}$ 794 (1996).

13. Y. -F. Wu, B. P. Keller, S. Keller, D. Kapolnek, P. Kozodoy, S. P. DenBaars and U. K. Mishra, Appl. Phys. Lett. 691438 (1996).

14. N. X. Nguyen, B. P. Keller, S. Keller, Y. F. Wu, M. Le, C. Nguyen, S. P. DenBaars, U. K. Mishra and D. Grider, Electron. Lett. 33334 (1997).

15. H. P. Maruska (private communication).

16. J. S. Williams. Rep. Prog. Phys. 49491 (1986).

17. S. J. Pearton, J. S. Williams, K. T. Short, S. T. Johnson, D. C. Jacobsen, J. M. Poate, J. M. Gibson and D. O. Boerma, J. Appl. Phys. 651089 (1989).

18. H. H. Tan, J. S. Williams, J. Zou, D. J. H. Cockayne, S. J. Pearton, J. C. Zolper and R. A. Stall, Appl. Phys. Lett. 721190 (1998).

19. J. C. Zolper, J. Han, R. M. Biefeld, S. B. Van Deusen, W. R. Wampler, S. J. Pearton, J. S. Williams, H. H. Tan, R. Karlicek and R. A. Stall, Mat. Res. Soc. Symp. 468 (1997).

20. J. C. Zolper, J. Han, R. M. Biefeld, S. B. Van Deusen, W. R. Wampler, D. J. Reiger, S. J. Pearton, J. S. Williams, H. H. Tan and R. Stall, J. Electron. Mater (to be published). 
21. S. J. Pearton, C. R. Abernathy, C. B. Vartuli, J. C. Zolper, C. Yuan and R. A. Stall, Appl. Phys. Lett. 671435 (1995).

22. S. Porowski and I. Grzegory, in GaN and Related Materials, ed. S. J. Pearton (Gordon and Breach, NY 1997).

23. N. Newman, In GaN Vol. I, ed. J. Reenkove and T. D. Moustakas (Academic Press, NY 1998).

24. J. C. Zolper, J. Han, S. B. Van Deusen, M. H. Crawford, R. M. Biefeld, J. Jun, T. Suski, J. M. Baranowski and S. J. Pearton, 1997 Fall MRS Meeting.

25. J. C. Zolper, D. J. Reiger, A. G. Baca, S. J. Pearton, J. W. Lee and R. A. Stall, Appl. Phys. Lett. 69538 (1996).

26. J. Hong. J. W. Lee, J. D. MacKenzie, S. M. Donovan, C. R. Abernathy, S. J. Pearton and J. C. Zolper, Semicon. Sci. Technol. 121310 (1997). 

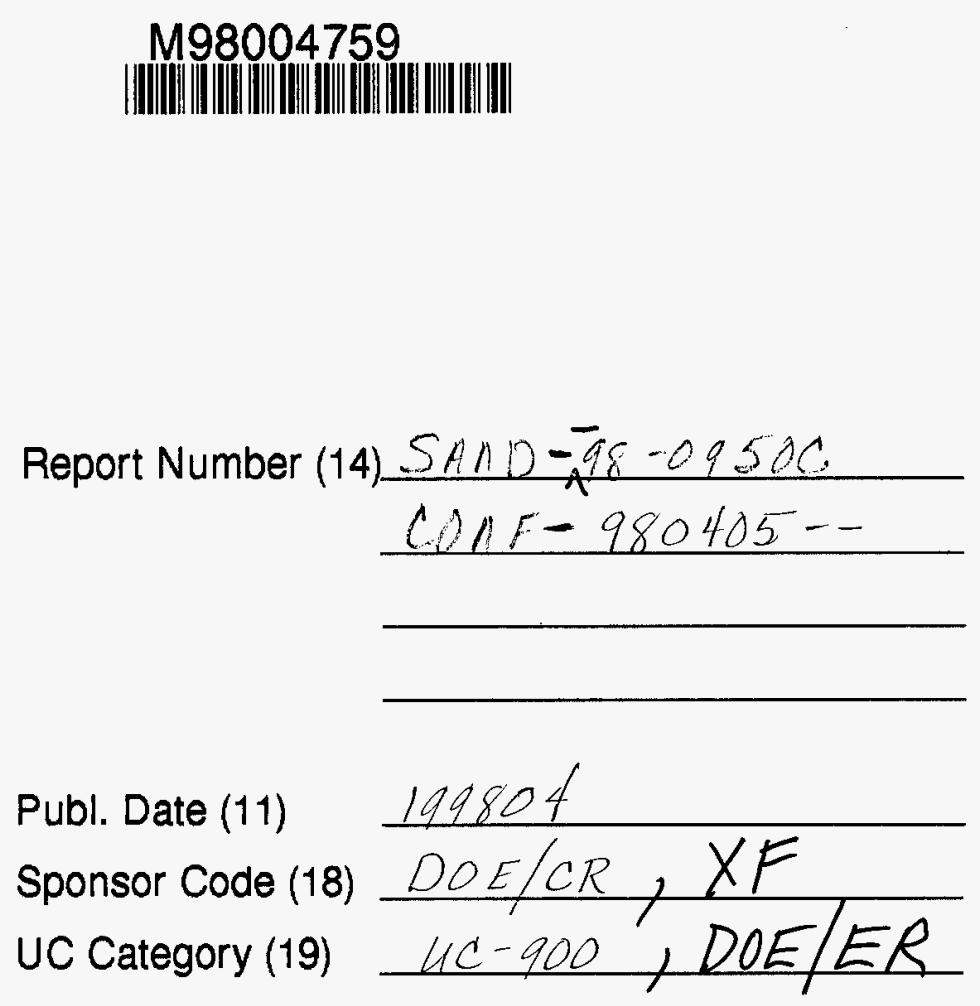